\title{
Maternal diabetes in the rat impairs the formation of neural-crest derived cranial nerve ganglia in the offspring
}

\author{
J. Cederberg 1 , J. J. Picard ${ }^{2}$, U. J. Eriksson ${ }^{1}$ \\ ${ }^{1}$ Department of Medical Cell Biology, Uppsala University, Uppsala, Sweden \\ 2 Unit of Developmental Genetics, Université Catholique de Louvain, Bruxelles, Belgium
}

\section{Abstract}

Aims/hypothesis. Maternal diabetes mellitus increases the risk for fetal malformations. Several of these malformations are found in organs and tissues derived from the neural crest. Previous studies have shown changes in fetal organs of neural crest origin in experimental diabetes and changes in migration of neural crest cells exposed to high glucose in vitro.

Methods. We used whole-mount neurofilament staining of embryos from normal and diabetic mothers to investigate the development of cranial nerve ganglia. Neural tube explants were cultured in 10 and $40 \mathrm{mmol} / \mathrm{l}$ glucose and cell death and caspase activity was measured with flow cytometry.

Results. The development of cranial ganglia V, VII, VIII, IX and X was impaired in day 10-11 embryos of diabetic rats. There was also a higher rate of cell death of neural crest derived cells cultured in $40 \mathrm{mmol} / \mathrm{l} \mathrm{glu}$ -
\end{abstract}

cose for $20 \mathrm{~h}(35 \%$ compared to $12 \%$ in $10 \mathrm{mmol} / \mathrm{l})$. However, exposure of cells to $40 \mathrm{mmol} / \mathrm{l}$ glucose in culture did not increase the activation of the cell death effector proteins-caspases-measured as cellular binding of the activated caspase marker VAD-FMK. This suggests that the cell death is not caused by caspasedependent apoptosis or that the caspases are activated at an earlier stage.

Conclusion/interpretation. The development of neural crest-derived structures is disturbed already at the organogenic period in embryos of diabetic rats and this deteriorated development could be due to high-glucose induced increase in cell death of neural crest derived cells. [Diabetologia (2003) 46:1245-1251]

Keywords Pregnancy, malformations, cell death, cranial nerve ganglia, whole embryo immunohistochemistry, FACS.
Maternal Type 1 diabetes is associated with an increased risk for adverse fetal outcome despite intense modern insulin treatment. The incidence of fetal malformations is reported to be between 4 to $10 \%$ or two- to fourfold the incidence in non-diabetic preg-

Received: 28 October 2002 / Revised: 23 December 2002 Published online: 27 June 2003

CC Springer-Verlag 2003

Corresponding author: Dr. J. Cederberg, Department of Medical Cell Biology, Uppsala University, Box 571, BMC 75123 Uppsala, Sweden

E-mail: jonas.cederberg@medcellbiol.uu.se

Abbreviations: N, Embryo of non-diabetic mother; MD, embryo of diabetic mother; FITC, fluorescein isothiocyanate; VAD-FMK, Val-Ala-Asp-fluoromethyl ketone. nancy $[1,2,3]$. Recently, an increased rate of malformations has been reported also in Type 2 diabetes [4, 5]. The teratogenic mechanisms are not known with certainty, although a large number of hypotheses are under investigation [6]. At present, it is not understood what structures or cell types in the embryo are primarily affected by the diabetic environment in the teratogenic process. Based on the types of malformations found in diabetic pregnancies, it has been suggested that the malformations are induced before the seventh week of gestation [7]. This is supported by the finding that experimental diabetes in the rat causes malformations during organogenesis at 6 to 10 days of pregnancy [8]. These epidemiological and experimental data suggest that maternal diabetes early in gestation exposes the developing embryo to an en- 
vironment capable of deteriorating the development of the fetus.

Neural crest-derived organs can display malformations in human diabetic pregnancy $[9,10]$ and in rodent pregnancy [11]. However, little is known whether maternal diabetes affects the neural crest cells during the embryonic period, and if so, even less is known by which means such an effect could be mediated. Nevertheless, it is known that high glucose concentrations in vitro can hamper the migration of neural crest-derived cells from neural tube of the rat embryo [12]. Moreover, neuroepithelial mitochondria from embryos of diabetic rats display altered morphology and metabolism compared to control mitochondria [13, 14]. These data suggest that the development of neural crest-derived structures can be disturbed by maternal diabetes and that these cells can be affected early in gestation. However, knowledge on how maternal diabetes affects the embryonic neuroepithelium and neural crest early in gestation remains scarce.

A possible means to characterise the effect of any teratogen on early neural crest development would be to study the effect of the teratogen on the development of the embryonic cranial nerve ganglia. This method has been used to investigate the toxicity of ethanol [15] and valproic acid [16] in mouse embryo development. The neurons of the cranial nerve ganglia V, IX and $\mathrm{X}$ originate mainly from different parts of the neural crest, whereas the neurons of ganglia VII, VIII mainly comes from the epidermal placodes with some contribution from the neural crest [17].

The aims of this study were to study early effects of maternal diabetes on development of cranial nerve ganglia and to examine if culture in high glucose concentrations affected survival of neural crest cells.

\section{Materials and methods}

Animals. Sprague-Dawley rats of the Uppsala substrain [18] with a weight of approximately $250 \mathrm{~g}$ were housed at the Laboratory Animal Resources at the Biomedical Centre of Uppsala University and subjected to a 12-h dark to 12-h light cycle. The rats had free access to tap water and the commercial food pellet R36 (Lactamin AB, Stockholm, Sweden). Rats that were to become diabetic were injected with streptozotozin (Sigma, St Louis, Mo., USA) $40 \mathrm{mg} / \mathrm{kg}$ in a tail vein. Blood glucose was measured one week after streptozotocin injection (Glucose Analyzer 2, Beckman Instruments, Fullerton, Calif., USA) and diabetes was defined as a glucose concentration exceeding $20 \mathrm{mmol} / \mathrm{l}$. At that time, the normal animals had a blood glucose concentration of $7.7 \pm 1.2 \mathrm{mmol} / \mathrm{l}$ and the diabetic animals $30.9 \pm 5.2 \mathrm{mmol} / \mathrm{l}$. Diabetic and control female rats were mated overnight with males of the same strain. The presence of sperm in vaginal smear defined day 0 of gestation. The rats were killed and the uteri removed at days 10 and 11 of pregnancy. All animal procedures were carried out according to the "Principles of laboratory animal care" (NIH publication no. 85-23, revised 1985) and were approved by the Animal Ethics Committee of the Medical Faculty of Uppsala University.
Cell culture. Embryos were dissected from the uteri and cleaned from uterine tissue using watchmakers' forceps. Neural tubes were dissected out of day 10 embryos with watchmakers' forceps, syringes and tungsten wires in glass rods. The neural tubes were incubated for $5 \mathrm{~min}$ in dispase (Boeringer Mannheim, Mannheim, Germany) diluted in water 1:10 (v/v) and thereafter rinsed of all non-neural tube tissue. The entire tubes were transferred to cell culture dishes.

The neural tubes were cultured in an atmosphere of $5 \%$ $\mathrm{CO}_{2}$ and $95 \%$ air in $37^{\circ} \mathrm{C}$ on $1 \mathrm{~cm} \varnothing$ cell culture dishes (Nunc, Roskilde, Denmark) coated with fibronectin (Sigma). The tubes were cultured in HAMs F12 medium with $15 \%$ fetal calf serum (Sigma Aldrich, Irvine, UK) and 5\% chick embryo extract (Life Technologies, Täby, Sweden).

To isolate cells migrating out from the neural tube, the tubes were allowed to grow for approximately $12 \mathrm{~h}$, during which cells migrated from the tubes onto the matrix. The tubes were thereafter removed and only the migrated cells were cultured for a further $20 \mathrm{~h}$ in either $10 \mathrm{mmol} / \mathrm{l}$ or $40 \mathrm{mmol} / \mathrm{l} \mathrm{glu}-$ cose. To determine that the cells growing out from the neural tube were neural crest cells, neural tubes were grown on glass slides for $24 \mathrm{~h}$ and thereafter fixed in ethanol. The slides were then stained with an antibody against the neural crest cell marker HNK-1 (Becton Dikinson, San Jose, Calif., USA), visualised using a peroxidase system and counterstained with haematoxylin $[19,20,21]$. Somite tissue was explanted and stained in the same manner as the negative control.

Detection of cell death and apoptosis. For analysis of cell death, the cells were incubated for $15 \mathrm{~min}$ at $37^{\circ} \mathrm{C}$ with propidium-iodide (Sigma) added directly to the culture medium to a final concentration of $10 \mu \mathrm{g} / \mathrm{ml}$. The cells were then washed with PBS with EDTA and released with Trypsin (Sigma), centrifuged and resuspended in PBS before FACS-analysis.

For analysis of apoptosis, the CaspACE FITC-VAD-FMK marker (Promega, Madison, Wis., USA) was added directly to the culture medium to a final concentration of $5 \mu \mathrm{mol} / \mathrm{l}$. The cells were incubated with the FITC-VAD-FMK marker for $20 \mathrm{~min}$ at room temperature. The cells were released as described above and thereafter fixed in $0.5 \%$ paraformaldehyde for 30 min before FACS-analysis.

After both propidium-iodide and CaspACE FITC-VAD-FMK incubation the cells were analysed using a Becton Dickinson FACSCalibur fluorescence activated flow cytometer (Beckton Dickinson Immunocytometry systems, San Jose, Calif., USA) with regard to forward scatter and FL3 (propidium-iodide) or FL1 fluorescence (CaspACE FITC-VAD-FMK). For each single observation, 5000 cells were analysed. Data was analysed by using the CellQuest software (Becton Dickinson).

Whole embryo immmunohistochemistry. Embryos for wholemount immunohistochemistry were harvested on gestational day 10 and 11 at different time points during the day. The embryos were dissected free from uterine tissue and washed with PBS. Crown-rump length, head length and mandibular arch length were measured under a dissection microscope (Wild M3Z, Heerbrugg, Switzerland). The embryos were examined for large malformations; rotational defects and open neural tubes. Eight embryos of normal $(\mathrm{N})$ and eight of manifestly diabetic mothers (MD) were paired and used in the study. The embryos came from four normal and four diabetic pregnancies and the embryos within each pair had equal somite number, ranging between 26 to 34 somites. A maximum of two embryos came from each mother. All $30 \mathrm{~N}$ embryos and $17 \mathrm{MD}$ embryos were observed for gross malformations whereas only data from the eight pairs were used in the morphometric evaluation. The embryos were fixed in $3 \%$ paraformaldehyde for $6 \mathrm{~h}$ 


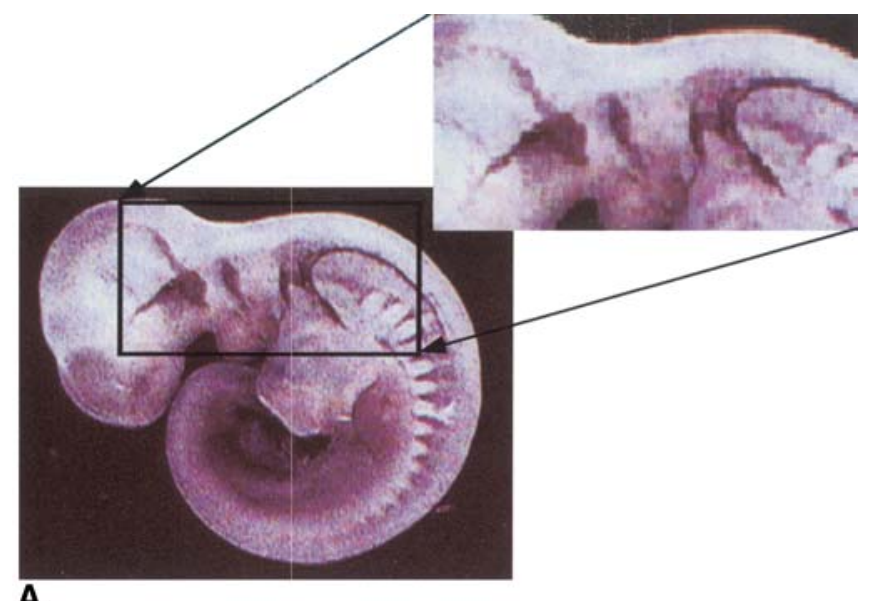

$\mathbf{A}$

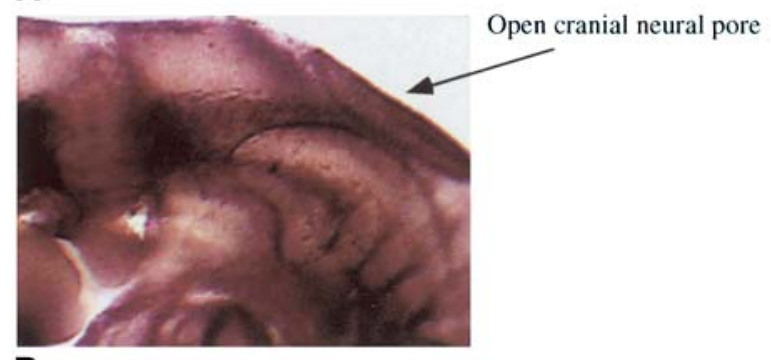

B

Fig. 1. A Left view of day-11 32-somite control embryo stained with the $2 \mathrm{H} 3$ antibody. $16 \times$ magnification. Cranial nerve- and spinal ganglia are visualised. The area containing the investigated cranial nerve ganglia is enlarged in the smaller picture to the upper right. B Left view of the area indicated in (A) of a 30somite embryo of a diabetic mother. The embryo displays abnormal non-closure of the cranial part of the neural tube and thereafter washed with PBS containing $50 \mathrm{mmol} / \mathrm{l} \mathrm{NH}_{4} \mathrm{Cl}$ $2 \times 1 \mathrm{~h}$ and $1 \times$ overnight. For increased permeability, a $24-\mathrm{h}$ treatment was carried out with PBS containing $10 \%$ FCS, $1 \%$ Triton $\mathrm{X}-100$ and $0.33 \% \circ \mathrm{H}_{2} \mathrm{O}_{2}$ at $4^{\circ} \mathrm{C}$. After three 1 -h washes in PBS the embryos were treated with the primary antibody 2H3 (Developmental Hybridoma Study Bank, Baltimore, Md., USA) diluted $1 / 100$ in PBS for $72 \mathrm{~h}$ at $4^{\circ} \mathrm{C}$ on rolling bars. The $2 \mathrm{H} 3$ antibody recognises the $155 \mathrm{kD}$ neurofilament protein [22]. The embryos were washed $3 \times 1 \mathrm{~h}$ in PBS and then incubated with a secondary antibody (peroxidase conjugated sheep anti-mouse, Boeringer Mannheim, Mannheim, Germany) diluted $1 / 40$ in PBS for $20 \mathrm{~h}$ and thereafter washed again as above. The peroxidase deposits were visualized using 4-chloro-1naphtol (Merck, Darmstadt, Germany). Embryos from diabetic and non-diabetic rats with equal number of somites were paired and treated together throughout the entire process.

The developmental stages of the cranial nerve ganglia $\mathrm{V}$, VII, VIII, IX and X were evaluated under a dissection microscope, scored according to a previously described system [15] and thereafter photographed. The total score for the ganglia V, VII, VIII, IX and X was then calculated for each embryo.

Statistics. The statistical methods used were the Wilcoxon signed rank test for the developmental scores of the ganglia and Student's paired $t$ test for parametric data regarding cell death and apoptosis. In all analyses, a $p$ value of less than 0.05 was used to define a significant difference. The software package Statview (SAS Institute, Cary, N.C., USA) for Macintosh computers was used for the statistical analyses.

\section{Results}

Gross morphology. The $2 \mathrm{H} 3$ antibody gave clear staining of neurofilaments in both cranial nerve gan-
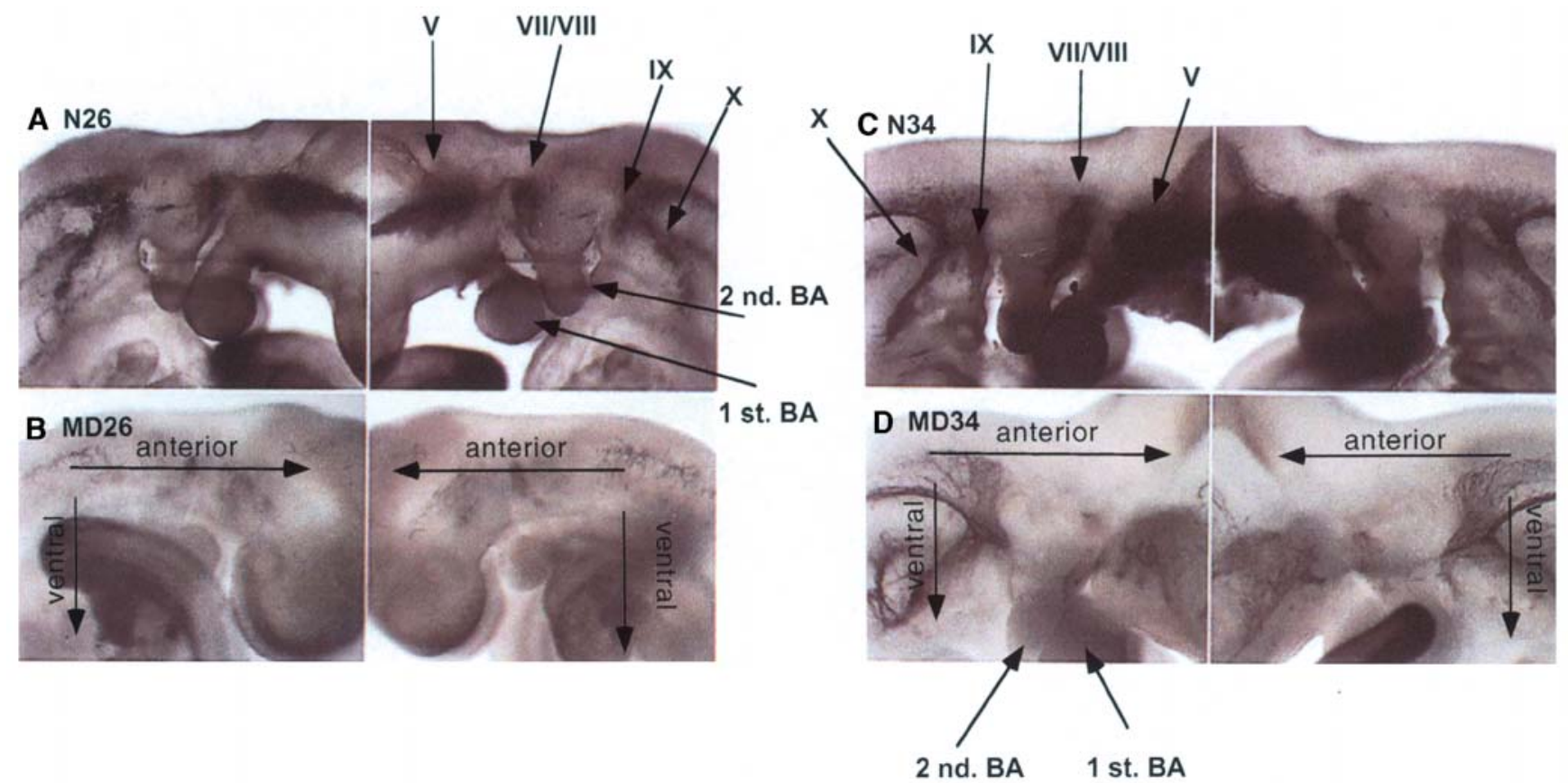

Fig. 2A-D. Staining of cranial nerve ganglia with the $2 \mathrm{H} 3$ anti-neurofilament antibody. Roman numerals denote ganglia, arabic the number of somites. BA=branchial arch. $40 \times$ magnification. The direction of the embryos is marked by the embryos in panels $\mathbf{B}$ and $\mathbf{D}$, the embryos in $\mathbf{A}$ und $\mathbf{C}$ are oriented corre-

spondingly. The photographs correspond to the enlarged area in Fig. 1A. A 26-somite embryo of normal mother. B 26somite embryo of diabetic mother. C 34-somite embryo of normal mother. D 34-somite embryo of diabetic mother 
A
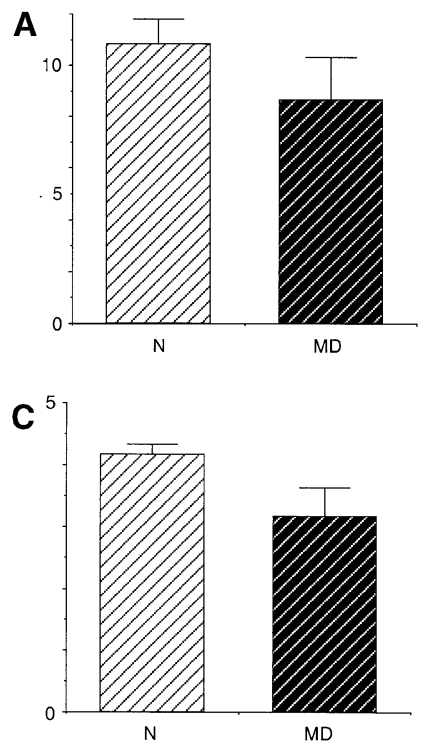

E

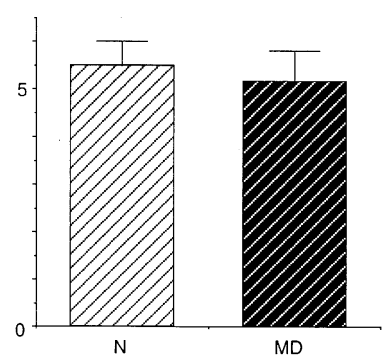

B
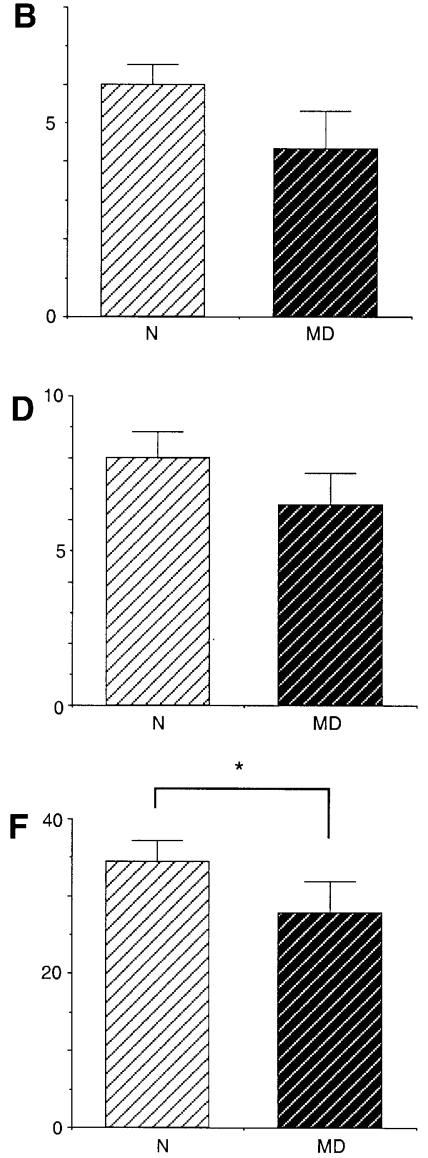

$\mathrm{N}$
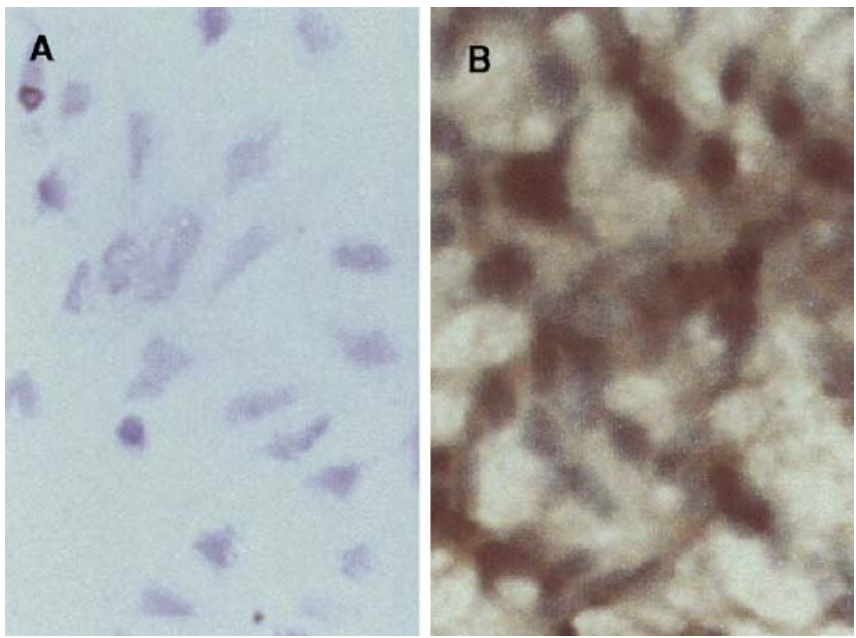

Fig. 4A, B. HNK-1 stained cells grown on glass slides for $48 \mathrm{~h}$. Haematoxylin used as background staining. A Cells growing out from explanted somite tissue. B cell growing out from the neural tube

Table 1. Morphometric data of the embryos. There were no significant differences between the N and MD goup

\begin{tabular}{lll}
\hline & $\begin{array}{l}\text { Embryos } \\
\text { of N rats }\end{array}$ & $\begin{array}{l}\text { Embryos } \\
\text { of MD rats }\end{array}$ \\
\hline Crown-rump length (mm) & $4.55 \pm 0.14$ & $4.33 \pm 0.34$ \\
Head length & $2.22 \pm 0.09$ & $1.92 \pm 0.24$ \\
Mandibular arch length & $0.25 \pm 0.02$ & $0.37 \pm 0.06$ \\
\hline
\end{tabular}

(Fig. 3F) in embryos of diabetic rats compared to the control embryos $(p<0.05)$. The mean crown-rump length was equal in embryos of normal and diabetic rats (Table 1), as was the mean head- and mandibular arch length

Cell death and apoptosis. Figure 4 shows explanted day 11 somite tissue (A) and neural tube-derived tissue (B) stained against the neural crest cell marker HNK-1. There is clear cytoplasmatic staining in the cells that have migrated out from the neural tube but nearly no staining at all in the cells coming from somite tissue. Figure 5 shows two representative FACS plots from one experiment with one culture with $10 \mathrm{mmol} / \mathrm{l}$ glucose culture $(\mathrm{A}, \mathrm{C})$ and one with $40 \mathrm{mmol} / \mathrm{l}$ glucose (B, D). Fig. 5E, F, G and $\mathrm{H}$ show 2-D plots corresponding to the histogram plots in A, $\mathrm{B}, \mathrm{C}$ and $\mathrm{D}$, respectively. The propidium iodide (Fig. 5E,F) and VAD-FMK (Fig. 5G,H) are plotted against the forward scatter (FSC) that gives a relative measure of cell size. A distinct second peak with high cell FL3 fluorescence is visible in the $40 \mathrm{mmol} / \mathrm{l}$ (Fig. 5B) experiment that is not seen in $10 \mathrm{mmol} / \mathrm{l}$ (Fig. 5A). As osmotic control, two experiments with $40 \mathrm{mmol} / \mathrm{l} \mathrm{L}$-glucose were also included where no increase in propidium-iodide staining was seen. In con- 

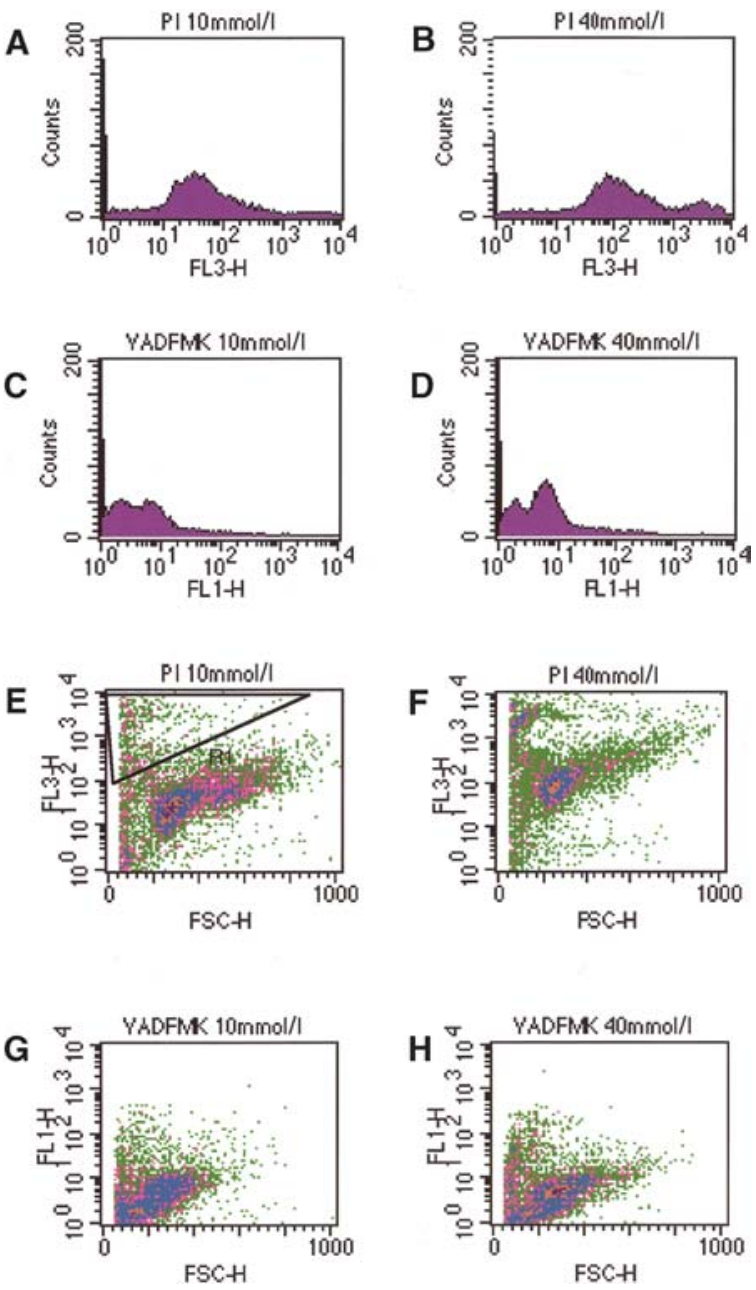

Fig. 5A-H. Results of FACS analysis. A and B Distribution of neuroepithelial cells according to propidium iodide staining after 20 -h culture in A $10 \mathrm{~mol} / \mathrm{l}$ glucose and B $40 \mathrm{~mol} / \mathrm{l}$ glucose after 20-h culture. C und D Distribution of neuroepithelial

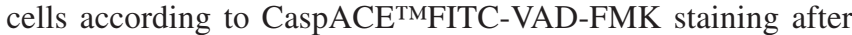
20 -h culture in C $10 \mathrm{~mol} / \mathrm{l}$ glucose and $\mathbf{D} 40 \mathrm{~mol} / \mathrm{l}$ glucose. Fig. 4E, Fig. 4F, Fig. 4G and Fig. 4H are 2-D plots corresponding to $\mathbf{A}, \mathbf{B}, \mathbf{C}$ and $\mathbf{D}$ respectively. FSC = Forward Scatter (corresponding approximately to cell size). The cell within the indicated area in $\mathbf{E}$ are defined as propidium-iodide positive

trast to the PI-staining, no change in the distribution of cells was seen when using the CaspACE FITCVAD-FMK marker (Fig. 5C,D), indicating an unchanged degree of caspase-dependent apoptosis. The limit used to single out dead cells from living cells is shown (Fig. 4E).

In Fig. 6 the compiled results of the FACS-data are shown. The rate of propidium iodide-positive cell was then approximately $12 \%$ in cells cultured in $10 \mathrm{mmol} / \mathrm{l}$ glucose whereas more than $35 \%$ of cells cultured in $40 \mathrm{mmol} / \mathrm{l}$ glucose for $20 \mathrm{~h}$ were proidium iodide-positive (Fig. 6A, $p<0.001$ ). However, culture in $40 \mathrm{mmol} / \mathrm{l}$ glucose for $20 \mathrm{~h}$ did not cause any change in the mean cellular FITC-VAD-FMK fluorescence (Fig. 6B).
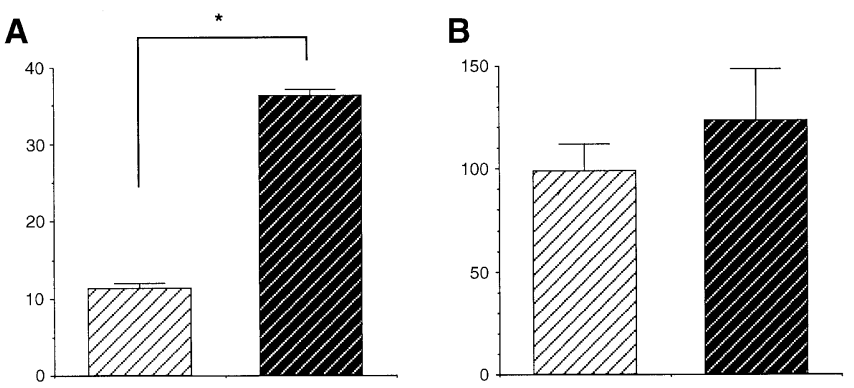

Fig. 6A, B. Fluorescence data in cells cultured in 10 und $40 \mathrm{~mol} / \mathrm{l}$ for $20 \mathrm{~h}$. A Percentage of propidium-iodide positive cells “*” denotes $p<0.001$. B Mean FITC-VAD-FMK fluorescence. No extra peak was found for the FITC-VAD-FMK fluorescence and the mean fluorescence is therefore reported. White hatched bars $10 \mathrm{~mol} / 1$ glucose; black hatched bars $40 \mathrm{~mol} / \mathrm{l}$ glucose

\section{Discussion}

The main finding in this study was that maternal diabetes impaired the embryonic development of neural crest-derived cranial ganglia. Moreover, we found evidence that cells from the neural crest at day 10 are sensitive to in vitro culture in a high glucose concentration. Our findings support previous results showing that experimental maternal diabetes can interfere with the development of neural crest-derived tissues. This study has indicated that the in vitro migration is affected by high glucose concentrations [12].

The development of cranial nerve ganglia in the MD embryos was delayed compared to that of the $\mathrm{N}$ embryos in our study. This delay is present despite the MD embryos being approximately $18 \mathrm{~h}$ older than the $\mathrm{N}$ embryos with equal somite number and size. Therefore, this altered ganglionic development represents a specific delay in the development of the cranial nerve ganglia in addition to the more general developmental delay seen in experimental diabetic pregnancy. The main part of the nerve cells and all supporting cells in these ganglia originate from the neural crest, the remaining neurons are derived from ectodermal placodes [17]. Studies in avian embryos indicate that the neural crest cells form mainly the proximal parts of the cranial nerve ganglia [17]. A delay in the development of the cranial nerve ganglia is therefore likely to reflect a delayed or altered migration of cells from the neural crest to the site of the cranial ganglia or a defect in the proliferation of these cells. We did not evaluate whether the altered development is only a delay which is recovered later in gestation or if it is a phenomenon of deteriorated development persisting as a functional defect in the newborn. Obviously, the development of other neural crest cell-derived organs (e.g. some cardiac structures) is disturbed for future life $[9,11]$.

The staining HNK-1 staining in Fig. 4 indicates that nearly all of the cells migrating out from the neu- 
ral tube in our culture system are neural crest cells and not fibroblasts, for example. A high glucose concentration in in vitro culture clearly increased the FACSanalysed propidium-iodide binding to the cells as a measure of increased cell death. However, no increase in FITC-labelled VAD-FMK binding to the cells was seen under these circumstances, thus indicating that the caspase system was not activated. It is possible that the caspase system was activated at an earlier stage by high glucose and not detected by us, or that a caspase-independent apoptosis programme [23] was activated. We did not find evidence of glucose-induced apoptosis [24] in this setting, but this can not be excluded. In fact, experimental diabetes in mice resulted in increased embryonic apoptosis in the unfused portion of the neural tube [25, 26], indicating that neural crest cells could undergo apoptosis due to high glucose concentrations. These studies also showed that gene expression of the transcription factor Pax3 was reduced by maternal diabetes and hyperglycaemia $[25,26]$. Null mutation of Pax3 has, moreover, induced neuroepithelial apoptosis $[25,26]$ and migratory failure of cardiac neural crest cells [27]. However, our laboratory has not found any decreased levels of Pax 3 mRNA in day 10 or 11 embryos of diabetic rats. Provided that there is an increased cell death also in the cells migrating from the crest, it can be assumed that the delay in cranial nerve ganglion development is due to enhanced cell death rather than merely a delayed neural crest-cell migration. Moreover, the malformations induced by diabetic pregnancy are often attributed to free oxygen radicals [28, 29, $30,31]$ and the neural crest cells are reported to have low activity of the radical scavenging enzyme superoxide dismutase [32]. The combination of increased oxidative stress and a cell type with low antioxidant capacity could therefore cause the malformations present in neural crest-derived organs in diabetic pregnancy.

At equal somite numbers, the embryonic morphometric measures did not differ between the $\mathrm{N}$ and the MD group. The embryos from the control mothers were thus as large as the embryos of the diabetic mothers. As the MD embryos are older than the $\mathrm{N}$ embryos, this illustrates the general developmental delay caused by maternal diabetes.

In mice, retinoic acid gave craniofacial malformations similar to those seen in rats subjected to maternal diabetes [11, 33]. Of note, neuroepithelial cell death and aberrant neural crest-cell migration has been shown to contribute to facial malformations induced by ethanol $[34,35]$ and retinoic acid $[36,37]$. Also, experimental diabetes in recent studies increased the teratogenic effect of retinoic acid [38] and of toxaphene [39]. These data suggest similarities between the teratogenic actions of several specific teratogenic substances and maternal diabetes mellitus. The mechanisms for diabetic teratogenicity are perhaps the least well understood, probably due to the multitude of interacting teratogenic substances in diabetes mellitus $[40,41,42]$. Further insight in the teratogenic actions of maternal diabetes could therefore also cross-fertilise the understanding of other teratogens.

We have thus shown that the development of the cranial nerve ganglia is delayed, corrected for developmental stage, in embryos of STZ-diabetic rat mothers compared to control embryos. Our results also indicate that more neural crest-derived cells die at a high glucose concentration than in a normal glucose concentration. However, we find no evidence for an increase in general caspase activity that could have confirmed previous data on diabetic embryopathy and apoptosis. The data from this study suggest that the development of neural crest cell-derived structures is specifically altered or delayed by maternal diabetes already during morphogenesis in the rat embryo and that this abnormality could be caused by hyperglycaemia-induced cell death.

Acknowledgements The authors are grateful to Dr. Van Maele-Fabry for sharing her knowledge of cephalic ganglia development. The Ernfors Family Fund and The Swedish Medical Research Council (Grant No. 12X-7457 and 12X-109) supported this study.

\section{References}

1. Casson I, Clarke C, Howard C et al.(1997) Outcomes of pregnancy in insulin dependent diabetic women: results of a five year population cohort study. BMJ 315:275-278

2. Hawthorne G, Robson S, Ryall EA, Sen D, Roberts SH, Ward Platt MP (1997) Prospective population based survey of outcome of pregnancy in diabetic women: results of the Northern Diabetic Pregnancy Audit. BMJ 315:279-281

3. Suhonen L, Hiilesmaa V, Teramo K (2000) Glycaemic control during early pregnancy and fetal malformations in women with type I diabetes mellitus. Diabetologia 43:79-82

4. Towner D, Kjos SL, Leung B et al.(1995) Congenital malformations in pregnancies complicated by NIDDM. Diabetes Care 18:1446-1451

5. Brydon P, Smith T, Proffitt M, Gee H, Holder R, Dunne F (2000) Pregnancy outcome in women with type 2 diabetes mellitus needs to be addressed. Int J Clin Pract 54:418-419

6. Eriksson UJ, Borg LAH, Cederberg J et al.(2000) Pathogenesis of diabetes-induced congenital malformations. Ups J Med Sci 105:53-84

7. Mills JL, Baker L, Goldman AS (1979) Malformations in infants of diabetic mothers occur before the seventh gestational week. Implications for treatment. Diabetes 28:292293

8. Eriksson RSM, Thunberg L, Eriksson UJ (1989) Effects of interrupted insulin treatment on fetal outcome of pregnant diabetic rats. Diabetes 38:764-772

9. Ferencz C, Rubin JD, McCarter RJ, Clark EB (1990) Maternal diabetes and cardiovacular malformations: predominance of double outlet right ventricle and truncus arteriosus. Teratology 41:319-326

10. Novak RW, Robinson HB (1994) Coincident DiGeorge anomaly and renal agenesis and its relation to maternal diabetes. Am J Med Genet 50:311-312 
11. Simán CM, Gittenberger-de Groot AC, Wisse B, Eriksson UJ (2000) Neural crest related malformations in offspring of diabetic rats decrease with vitamin E treatment. Teratology 61:355-367

12. Suzuki N, Svensson K, Eriksson UJ (1996) High glucose concentration inhibits migration of rat cranial neural crest cells in vitro. Diabetologia 39:401-411

13. Yang X, Borg LA, Eriksson UJ (1995) Altered mitochondrial morphology of rat embryos in diabetic pregnancy. Anat Rec 241:255-267

14. Yang X, Borg LAH, Eriksson UJ (1997) Altered metabolism and superoxide generation in neural tissue of rat embryos exposed to high glucose. Am J Physiol 272:E173-E180

15. Van Maele-Fabry G, Gofflot F, Clotman F, Picard JJ (1995) Alterations of mouse embryonic branchial nerves and ganglia induced by ethanol. Neurotoxicol Teratol 17:497-506

16. Gofflot F, Maele-Fabry G van, Picard JJ (1996) Cranial nerves and ganglia are altered after in vitro treatment of mouse embryos with valproic acid (VPA) and 4-en-VPA. Brain Res Dev Brain Res 93:62-69.

17. D'Amico-Martel A, Noden DM (1983) Contributions of placodal and neural crest cells to avian cranial peripheral ganglia. Am J Anat 166:445-468

18. Eriksson UJ (1988) Importance of genetic predisposition and maternal environment for the occurrence of congenital malformations in offspring of diabetic rats. Teratology 37: 365-374

19. Tucker GC, Delarue M, Zada S, Boucaut JC, Thiery JP (1988) Expression of the HNK-1/NC-1 epitope in early vertebrate neurogenesis. Cell Tissue Res 251:457-465

20. Erickson CA, Loring JF, Lester SM (1989) Migratory pathways of HNK-1-immunoreactive neural crest cells in the rat embryo. Dev Biol 134:112-118

21. Nishida A, Kobayashi T, Ariyuki F (1997) In vitro developmental toxicity of concanavalin A in rat embryos: analysis of neural crest cell migration using monoclonal antibody HNK-1. Teratog Carcinog Mutagen 17:103-114

22. Dodd J, Morton SB, Karagogeos D, Yamamoto M, Jessell TM (1988) Spatial regulation of axonal glycoprotein expression on subsets of embryonic spinal neurons. Neuron 1:105-116

23. Leist M, Jaattela M (2001) Four deaths and a funeral: from caspases to alternative mechanisms. Nat Rev Mol Cell Biol 2:589-598

24. Durrieu F, Belloc F, Lacoste L et al.(1998) Caspase activation is an early event in anthracycline-induced apoptosis and allows detection of apoptotic cells before they are ingested by phagocytes. Exp Cell Res 240:165-175

25. Phelan SA, Ito M, Loeken MR (1997) Neural tube defects in embryos of diabetic mice. Role of the Pax-3 gene and apoptosis. Diabetes 46:1189-1197

26. Fine EL, Horal M, Chang TI, Fortin G, Loeken MR (1999) Evidence that elevated glucose causes altered gene expression, apoptosis, and neural tube defects in a mouse model of diabetic pregnancy. Diabetes 48:2454-2462

27. Conway SJ, Henderson DJ, Copp AJ (1997) Pax3 is required for cardiac neural crest migration in the mouse: evidence from the splotch $(\mathrm{Sp} 2 \mathrm{H})$ mutant. Development 124:505-514.
28. Eriksson UJ, Borg LAH (1991) Protection by free oxygen radical scavenging enzymes against glucose-induced embryonic malformations in vitro. Diabetologia 34:325331

29. Eriksson UJ, Borg LA (1993) Diabetes and embryonic malformations. Role of substrate-induced free-oxygen radical production for dysmorphogenesis in cultured rat embryos. Diabetes 42:411-419

30. Viana M, Herrera E, Bonet B (1996) Teratogenic effects of diabetes mellitus in the rat. Prevention with vitamin E. Diabetologia 39:1041-1046

31. Cederberg J, Galli J, Luthman H, Eriksson UJ (2000) Increased mRNA levels of Mn-SOD and catalase in embryos of diabetic rats from a malformation-resistant strain. Diabetes 49:101-107

32. Davis WL, Crawford LA, Cooper OJ, Farmer GR, Thomas DL, Freeman BL (1990) Ethanol induces the generation of reactive free radicals by neural crest cells in vitro. J Craniofac Genet Dev Biol 10:277-93

33. Yasuda Y, Okamoto M, Konishi H, Matsuo T, Kihara T, Tanimura T (1986) Developmental anomalies induced by all-trans retinoic acid in fetal mice: I. Macroscopic findings. Teratology 34:37-49

34. Kotch LE, Sulik KK (1992) Experimental fetal alcohol syndrome: proposed pathogenic basis for a variety of associated facial and brain anomalies. Am J Med Genet 44:168-176

35. Dunty WC Jr, Chen SY, Zucker RM, Dehart DB, Sulik KK (2001) Selective vulnerability of embryonic cell populations to ethanol-induced apoptosis: implications for alcohol-related birth defects and neurodevelopmental disorder. Alcohol Clin Exp Res 25:1523-1535

36. Yasuda Y, Konishi H, Kihara T, Tanimura T (1987) Developmental anomalies induced by all-trans-retinoic acid in fetal mice: II. Induction of abnormal neuroepithelium. Teratology 35:355-366

37. Yasuda Y, Itoh K, Mizuno N, Konishi H, Tanimura $\mathrm{T}$ (1989) Alterations in migrating cranial neural crest cells in embryos of mice fed retinoic acid. Anal Cell Pathol $2: 23-40$

38. Chan BW, Chan KS, Koide T et al. (2002) Maternal diabetes increases the risk of caudal regression caused by retinoic acid. Diabetes 51:2811-2816

39. Calciu C, Kubow S, Chan HM (2002) Interactive dysmorphogenic effects of toxaphene or toxaphene congeners and hyperglycemia on cultured whole rat embryos during organogenesis. Toxicology 175:153-165

40. Sadler TW, Hunter ES, Wynn RE, Phillips LS (1989) Evidence for multifactorial origin if diabetes-induced embryopathies. Diabetes 38:70-74

41. Buchanan TA, Denno KM, Sipos GF, Sadler TW (1994) Diabetic teratogenesis. In vitro evidence for a multifactorial etiology with little contribution from glucose per se. Diabetes 43:656-660

42. Styrud J, Thunberg L, Nybacka O, Eriksson UJ (1995) Correlations between maternal metabolism and deranged development in the offspring of normal and diabetic rats. Pediatr Res 37:343-353 